\title{
Explanation of Akidah in the Works of Patani Ulama and its Relation to Method of Aqidah Hurairan By Imam Al-Nawawi
}

\author{
Abdulhadee Sabuding ${ }^{1}$ \\ 1/slamic studies: Akidah, Pensyarah Jabatan Pengajian Islam, College Pengajian Islam, \\ Prince of Songkla University (PSU). Pattani Campus, Thailand. \\ Email: sabdulha@bunga.pn.psu.ac.th \\ Accepted Article: 20 August 2014 \\ Published Article: 20 April 2015
}

\begin{abstract}
This article discuss about method of explanation of akidah in the work of patani ulama and and method of explanantion of imam al-Nawawi about akidah and recognizing clearlly similarities of method of explanation of ulama patani with imam al-Nawawi. The article is qualitative study using library risearch and analytical data in the form of descriftive with two principle of deductive an inductive. Researh findings show that method of al-nawawi in explaining aqidah is a combination of Salaf and Khalaf, but patani ulama use rather the khalaf method. This study also shows that there is a similar method between the two different ulama in dealing with explanation of aqidah. However, there are also points of different between them in the way they use Salaf and khalaf. Imam al_Nawawi uses Salaf method for the first following by Khalaf on the contrary the Patani Ulama applied Khalaf as starting point followed by Salaf.
\end{abstract}

Keywords: Method of aqidah explanation, Imam al-Nawawi, the works of Patani Ulama

\section{A. INTRODUCTION}

Islamic aqidah derives from Qur'an and Sunnah of Prophet and are implemented by man of the past such as sahabah, tabi'in, tabi'i tabi'in and atba tabi'i tabi'in in the period of the firts three hundred of hijra and subsequentlly followed by the ulama. So, the way to understand qur'anic verses and Sunnah of prophet relating to verses and hadist of sifat and Qur'anic verses and hadist mutasabihat, between ithbat and takwil. It has a relation to the explanantion of akidah in the patani ulama al-Nawawi.

The theme of the title is no information toward this study especially explanation of Patani ulama and imam al-Nawawi. In the same time, explanation is important fo Islamic society in Patani due to its akidah to akidah discussion directly. The study emphasizes the works of ulama in Patani and method of Tafsir imam al-Nawawi and clearly understood method of akidah explanation among the ulama in Patani and imam al-Nawawi.

\section{B. METHODS}

The article is qualitative study using library research and analytical data in the form of descriptive with the deductive an inductive principles. 


\section{RESULT AND DISCUSSION}

\section{The Works of Ulama in Patani}

Study on the works of ulama in patani shows that akidah explanation of their work as follow:

Firts: al-Dur al-Thamin fi Bayan aqaid al-Mu'min (الدالثمين في بيان عقائد المؤ منين), by syeikh Dud al-Fatani in Malay language but in Jawi letter. Method of aqidah explanation used by syeikh Daud in his book based on explanation of khalaf. For instant, he explains the character of Allah based of twenty characters:

$$
\text { فرتام وجب وجود ارتيب وجود ايت ادا دان معناث يآيت يغ تياد دكنل اكن ذات سوات دغن }
$$

كتيادائن ارتيث تياد دكنل ذات سوات ملينكن افبيل ادا موجود اتو اغكو كات يآيت يغ تياد دعقلكن صفة فدا يغ موصوف دغن كتيادان ارتيث تياد كنل صفة سوات يغ بر ايت ملينكن افبيل ادا موجود (Idris, n.d.)

When he explains the character of mukhalafah lil hawadith he said:

$$
\begin{aligned}
& \text { يعين تياد وجب وجود دات سوات سفرت ذات الله كارن ذات الله بو كان جنيس نور دان تياد جنيس } \\
& \text { كجدين لا غيت دان بومى دان بر غيغ انتار اكدواث دان تياد صف سوات سفرت صفة الله كارن صفة } \\
& \text { ايت قديم لآك باقى }
\end{aligned}
$$

(Idris, n.d.)

When he explains bait sya'ir Ibrahim Al-Luqani in the character of mustahil of Allah as follow:

$$
\text { (و كل نص أوهم التشبيها اوله اوفوض ورم تنزيها) }
$$

دان تيف2 نص قرأن دان حديث يغ مواهمكن اى اكن سروف دغن يغ بهارو سفرة منو بخوقكن ادا برجهة سفرة فرمانث (يخافون رهم من فوقهم ) تاكوة مريكئيت اكن توهن مريكئب درفذ اتس مريكئب مك ميات كن اية كادائن توهن فيهق اتس اتو منو بنوقكن بر جسم سفرة (وجاء ربك) دان تله داتغ توهنمو مك اداله أية اين منو بجوقكن بر جسم كارن داتغ تياد دكتاكن ادا جسمت

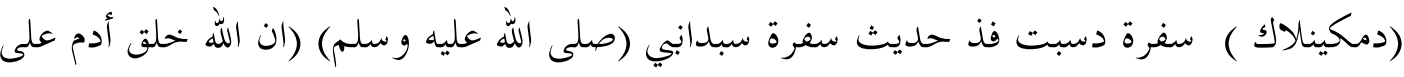
صورته) هو اسث منجديكن أدم اتس روفاث مك اداله منو بخوقكن اداله بك الله روفا دان منو بخوقكن براغكوتا سفر فرمانث (ويبقى وجه ربك, يد الله فوق ايديهم) دان تغكل ايت وجهه توهنم دان تاغن الله داتس تاغن مريكئيت مك اداله دوا أية اين منو بنوقكن برغكوتا مك الخلف واجب وكيت تأو يلكن 


$$
\begin{aligned}
& \text { يعنى تغكغكن أتس ميالهى ظاهرث اى مك دتأ يلكن دأتس كتغكين دان كبسارن بو كان دأتس تمفتث }
\end{aligned}
$$

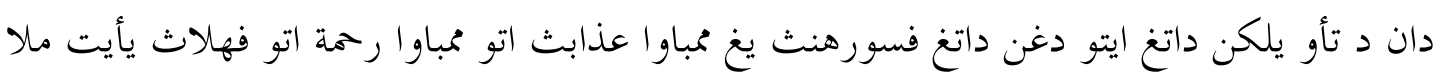

$$
\begin{aligned}
& \text { ئكة دان مو كاث ذاتث دان تاغنث ايت قدرتث دنمكينله د تأو يلكن تيف2 اية اتو حديث يغ ممبرى } \\
& \text { وهم اكن ميروفائي همارو اين مذهب الخلف ادافون مذهب السلف ايت اداله مريكئيت تفويض علموث } \\
& \text { ايت كفدا الله دان فذا ظاهر كتاث دان فذا حقيقة كيت جاوهكن سكل ككور اغن سفرت كيت كات } \\
& \text { الله داتس كامى ارتي داتس تتافى كتهوي تياد كامى كتهوى حقيقتث سفرت كيت كات الله داتس } \\
& \text { تتافى تياد سفرت داتس سكال يغ هـار }
\end{aligned}
$$

(Idris, n.d.)

The explanation of Qur'anic verses and hadits muthasyabihat as typically Allah discussed in this works two opinions namely salaf and khalaf. But in innitialy it starts with khalaf and followed by salaf. by doing so, it is categorized as the combination method between khalaf and salaf that formerly used by the scholars of khalaf. In this works, there is no salaf method only in explaining the mustahil character of Allah.

Second: Aqidah al-Najin fi ilm ushul al-Din ( عقيدة الناجين في علم أصل الدين)by syeikh Zainal Abidin al-Fatani is in Malay but in Jawi letter as commentary of Umm Barahim of imam al-Sanusi. In the theme of character of mustahil of fifth character talking about jahl (ignorance), he said that they who depend on the literal kitab (book) and hadits muthsabihat are the nature of the kufur hasyawiyyah. In the Qur'an there are two types of verse that are muhkamah and muthasabihat. The former should be taken its meaning from its literal meaning without process of ta'wil and of the later, it has to take another relevant meaning beside its literal with qawaid syar'iyyah. He again said about kufur that is when people use literal meaning of a quranic verse and hadist muthasabihat and said with how to act as the dhahir verses into salaf. It is shown as he explain about sya'r ibrahim al-Luqani in the mustahil characther of Allah, he explain as follow:

$$
\begin{aligned}
& \text { (و كل نص أوهم التشبيها اوله اوفوض وررم تنزيها) } \\
& \text { ارتث تيف2 نص قرأن دان حديث يغ مبرى وهم اكن تشبه الله ايت دغن يغ هارو تأو يل اولهم اتو } \\
& \text { سرهكن اولهم فغتهوان ايت كفدالله دان قصد اولهم اكن سوج الله تعالى داري فدا ميروفائي دغن } \\
& \text { سكال هـارو , مراد داري فدا تشبه ايت ميروفائي دان مراد دغن تاويل ايت تغكغكن اتس برسلاهن } \\
& \text { ظاهرث سرت ميتاكن معن يغ دكهنداكى مك مراد دغن ايت تأو يل تفصيل سفرة بهو ادا فداث } \\
& \text { ميتاكن معن يغ دكهنداكى سفرة يرغيغ اى فدا مذهب الخلف. يغكدوا دان كتاث سرهكن سرهكن } \\
& \text { اولمم ارتيث كمدين يدفد تأو يل الجمالى يغ اي ممالغكن لفض يغ ممبرى وهم ايت داري فدا ظاهرث ملك }
\end{aligned}
$$

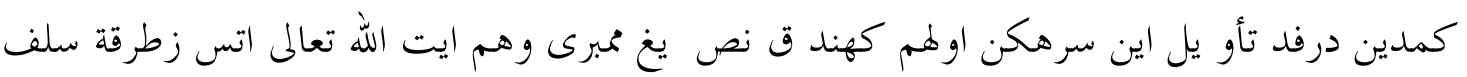

(Abidin, n.d.) 
He said that salaf with his word for him face, hands and all of its fingers that have no idea about them, for khalaf said that the meaning of the face is His essence and the meaning of the hand is His qudrah and the meaning of the finggers is rahman and two character of qudrah and iradah. From the explanation we can see clearlly that his explanation is a mix explanation between salaf and khalaf where it is started by khalaf and followed by salaf subsequently. For salaf, let's give all of the knowledge to Allah and for khalaf it should be interpreted by ta'wil. As it is so, the explanation of that type is the explanation of khalaf.

Third: miftah al-Murid fi ilm al-Tauhi (مفتاح المريد في علم التوحيد) by Syeikh Zainal Abidin in Malay but jawi letter. The book spoke about the twenty characters together with its logics. It started with the wajib character of Allah then paired with its contradiction. The model show two pairs of contradicting characters such as wujud (being) is explained regarding the character that is mustahil namely nothing (Abidin2, n.d.). This method reflects the approach of khalaf rather than salaf.

Forth: faridah al-fara'id fil ilm al-Aqa'id (فريدة الفر ائد في علم العقائدة) by Syeikh Ahmad in Malay but in Jawi letter. It is a book on tweenty characters of Allah. It is supported by logical argument as he explain the forth character Mukhalafat li al-Hawadith and its mustahil character as something new.

Qur'anic verses and hadith shows similar method as salaf put to Allah all the meaning and khalaf use ta'wil

$$
\text { كرمان: الله تعالى "الرحمن على العرش استوى" (طه: ) }
$$

(Al-Patani, n.d.)

Explanation on verse of sifah and muthasabihat using the two-method consecutivelly strated with salaf then khalaf in the following discussion is method of the scholars of khalaf.

Fifth: baqurah al-Amani li Irsyad awam ahl al-Patani (باكورة الامان لارشاد عوام اهل الفطان) by Ismail bin Abdul Qadir al-Patani in Malay but Jawi letter. The method of this book is also typical with the previous. The author use logical argument toward the wajid character of Allah together with the mustahil character. The book will started with the wajib character and accompanied by the mustahil sifah as it is reflect the khalaf method of explanation. For example the character of wujud as the greatest character attached to Allah followed by the mustahil of His mustahil (nothing) or unexist (Qadir, 2000).

Sixth: Unwan al-Falah wa Unfuwan al-Salah (عنوان الفلاح وعنفوان الصلاح) by Syeikh ahamad bin Mustafa bin Muhammad al-Patani. It's written in Malay but Jawi letter. It composes some matterial 
of ushuluddin as the strarting points. It discuss' Islam, Iman and Ihsan followed by the tweenty characters of Allah with its logical arguments, character of the Prophet, figh and akhlak (morals).

He puts forward the explanation of the obligatory for mukaalaf to know the supreme character of Allah and how the mukkalaf ought to understand the thriteen characters. His explanantion used the logical argument of the scholars of khalaf as he mentioned such as wujud (Al-Patani3, n.d.) viz a viz adam the mustahil.

Seventh: Al-Igd Al-Farid Fi Ilm Al-Tauhid (العقد الفريد في علم التوحيد) by Wan Islamil Bin Syeikh Ahmad Bin Muhammad Zin al-Patani. It is written in Malay but Jawi letter. The book is arranged as discussion of question-answer model toward the twenty characters of Allah using the khalaf method. He arrange put the wajib character of wujud with his mustahil adam (nil) (Al-Patani, n.d.) followed by logical and qur'anic arguments.

Eight: Mabhath Al-Kalam Fi IIm Kalam (مبحث الكام في علم الكلام) by Abdul Qadir bin Wangah. It is written in Malay but with Jawi letter. He put on his book the obligatory for mukaalaf to know the supreme character of Allah and how the mukkalaf ought to understand the thriteen characters. The different is that he use the logic argument and sometimes use Qur'an as it need. As with khalaf he explain the wujud by relating to new of nature as its supporting argument (Wangah n.d.).

Ninth: Risalah Manhaj Ahl Al-Sunnah (رسالة منهج أهل السنة) by Abdul Qadir bin Wangah. It is written in Malay but with Jawi letter. Most of the book depicts both muhkamat and muthsabihat verse in Qur'an in the same time. He explain how to tawil and explain the muthasabihat verse of the Qur'an.

$$
\begin{aligned}
& \text { فرمان الله تعالى: " الرحمن على العرش استوى" (طه: ) استوى يليق به ملك ارتى اية ايت توهن يغ }
\end{aligned}
$$

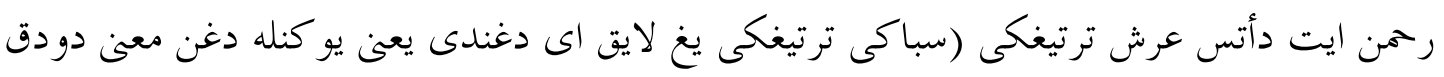

$$
\begin{aligned}
& \text { أتس دان دايكوتي كات ) } \\
& \text { هذه طرقة سلف الذى يفضون علم المتشابه. ومن ذللك جواب الامام مالك رضي الله عنه عنه معنى } \\
& \text { الاستوا على العرش فى حقه تعالى حيث قال تعالى للسائل الاستوا معلوم و الكيف بجهول والايمان به } \\
& \text { واجب و السؤال عنه بدعة اخرجوا عنى هذا المبتدع و واما الخلف وهم من بعد الخمسمالة فيقولون بمعن } \\
& \text { صحيح لائق به سبحانه و تعال فيقولون إن المرد بالستواء الإستيلاء با لتصرف و القهر فالاستواء له } \\
& \text { معنيان الركوب و الجلوس والاستيلا بالقهر و التصرف...) } \\
& \text { ارتي اين اياله جالنن سالف يغ ميرة مريكئيت اكن فغتهوان ايات بك الله تعال ستغه درفدا دمكين ايت } \\
& \text { جو اب امام ملك رضى الله عنه درفد معنى استواء ترتيغكى أتس عرش فذاحقن تعالى سكرا2 بركات ایى } \\
& \text { بك سؤرغيغ برتان برمول ترتيغكى ايت معلوم دان كيفية ايت دجهيلكندى دان بريمان دغنن ايت } \\
& \text { واجب دان تياد درفدان ايت بدعه هندكله مغلوارله كامو درفداكو اكن اين اورغيغ مبتدا, دان ادافون }
\end{aligned}
$$




$$
\begin{aligned}
& \text { خلف دان مريكئيت سوغكو هن يغد كهندقكي دغن ترتيغكى ايت مرنته دغن رنته دان مغراسي مك } \\
& \text { ترتيغكى ايت بكين دوا معنى فرتامن نأيك دان دودوق كدوا مرنته دان مغراسي دان رنته.... }
\end{aligned}
$$

(Wangah3, n.d.)

For example to use of khalaf and salaf in explaining muthasabihat verse about the characters of Allah and the hadith, it puts salaf method for the first and khalaf in the following explanation. It combines the way the salaf puts the knowledge as a matter of Allah, meanwhile khalaf use ta'wil to choose the best way for exlaining the appropiate one for Allah. The aim of khalaf is to avoid representation of Allah into his creature character. As it is clear to see the use of that way in his books, it reflects how khalaf is applied in the book.

Tenth: Risalah Irsyad al-Jawiyyin ila sabil al-Ulama al-amilin by Abdul Qadir bin Wangah in Malay but jawi letter. The book talks about the nature of the religion such as mauludin nabi, mazaz in Qur'an and hadith, the problems of tawasul and istiwa and so on and so forth. For istiwa he discusses:

$$
\text { فرمان الله تعالى: " الرحمن على العرش استوى" (طه: ) }
$$

(Wangah, n.d.)

He explains the muthasabihat verses consist of three groups. The firts group follow the zahir nas (literal) without ta'wil, second is the salaf and the third the khalaf.

It is evident from the explanation above that the author applied a khalaf method, as the salaf depend and put the real meaning to Allah and the khalaf chooses the ta'wil.

From the ten works, it is can be concluded five of them using khalaf and salaf methods in the same time in discussing muthasabihat verses. Meanwhile the other five books use only khalaf method whithout quoting to salaf.

\section{The life of Imam al-Nawawi and its Method of Explanation}

Imam Al-Nawawi Is Muhy Al Din Abu Zakaria Yahya Bin Syaraf Bin Mirra Bin Husain Bin Muhammad Bin Jum'ah bin Hizamiy al-Nwawy. His nawawi name is derived from the vilage in Hauran in Damascus, Syria. From the place he gets his famous name as al-Nawawi. He follows the Syafi'i school and is concerned more on figh of Syafi'i belittled "Muhy al-Din" or the "Religious" with Abu Zakariya (Al-Sakhawiy, n.d.) .

People know him as the greatest ulama for his time and the following generation until now. In the intellectual point of view, he produced a number of works for hadith and fiqih of Syafi'i and Aqidah. Khalaf also influences him as the mainstreams of his time.

His works are around: fiqh, ushul, mustalah, lughah and he wrote works like Riyad al-Salihin, AlManhaj, Syarh Sahih Muslim bin Hajjaj, Raudhah al-Talibin wa Undah al-Muttaqin and soon and so forth. 
The book of commentary to Sahih Muslim is put in the highest position in Muslim society until now. It is evident in the history as many of previous ulama before him that gave commentaries to the books. However, his commentary is one of comprehensive compared to the other such as alMaziriy and Qadi lyad.

\section{Method of Aqidah Explanation about the Character of Allah}

\section{For the method of al-Nawawi in his explanation}

He explains hadits about Allah's characters based on mixed method between two methods of salaf and khalaf, but the stress is on khalaf. It can be seen clearly if imam al-Nawawi explains hadits of character on Syarh Sahih Muslim, he said: "This hadits between hadits about Allah's character". This term indicates salaf school, then he explains second school, that's khalaf, and cites the scholars of khalaf to support this stream interpretation.

\section{Method Imam Al-Nawawi Explaining Hadiths about the Character of Allah}

Based on the explanation on syarh sahih Muslim, imam al-Nawawi analyzes the hadits about Allah's characters through mixed method of salaf then followed by Khalaf School. But, on khalaf stream he tends to explains the problems in question. His explanation is about language explanation and the meaning of nas.

Thus sometimes describes that he prefers to use the reason and and arguments of the scholars of khalaf. It's also confirmed that he tend to khalaf stream rather than salaf stream but he does not avoid salaf. For researcher of the syarh (commentaries) of the Sahih Muslim book it's clear that imam al-Nawawi's method in explaining hadits about Allah's character is mixed; he put together salaf and khalaf opinions when explains those haditses then continued with long explanation based on khalaf school. For example when he explains nuzul hadits that has been explained before in hadits no.758 and usbu's hadits no. 2786 and surah hadits no.182. Imam al-Nawawi said:

$$
\begin{aligned}
& \text { إعلم لإهل العلم في أحاديث الصفات وأيات الصفات قولين: احدهما: وهو مذهب معظم السلف او } \\
& \text { كلهم أنه لايتكلم في معنىاها, بل يقولون يجب علينا أن نؤمن بما ونعتقد لها معنى يليق بجلال الله تعالى }
\end{aligned}
$$

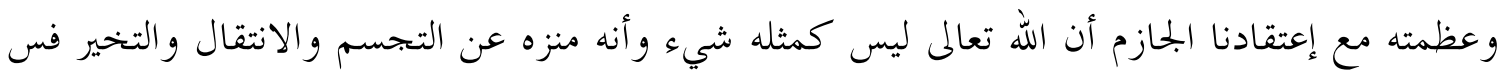

$$
\begin{aligned}
& \text { جهة وعن سائر صفات المخلوق. والقول الثانى: وهو مذهب معظم المتكلمين أها تتأولعلى ما يليق هـا } \\
& \text { على حسب موقعها, وانما يسوغ تأويلها لمن كان من اهله بأن يكون عارفا بلسان العرب وقواعد } \\
& \text { الاصول و الفروع }
\end{aligned}
$$

The meaning: this hadits is in between hadits about Allah's characters. This is a famous hadits character's method on salaf stream, when he does the "takwil" of Allah's characters as like nuzul to the descend of blessing, usbu' to the power and surah to the this surah of Adam describe explanation method of Allah's characters on khalaf stream opinion (Sabuding, 2013).

Iman Al-Nawawi preceedes salaf method briefly, then followed by khalaf stream with details explanation, example: 


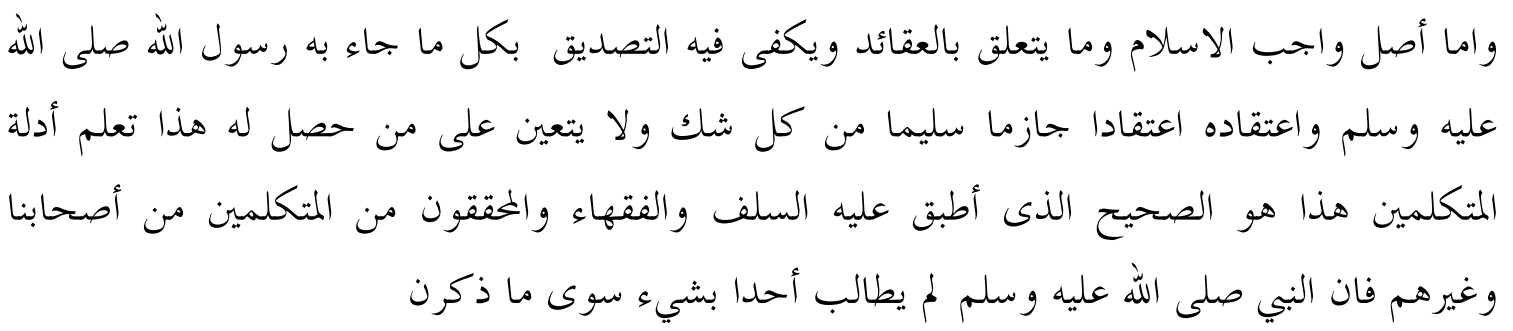

Meaning: Be cognizant by you that experts said hadits-hadits of character and ayah-ayah of character divided into two groups. First: salaf group is group who does not talk about meaning (Allah's character), then they said that we must believe in God and beri'tikad about meaning which is proper with Allah and his mighty, and i'tiqad by putus that Allah does not similar with anything, and Allah is clear from berlembaga, nomaden, menetapkan certain place dan clear from every creation's characters. Second: Mutakallimin (khalaf) group is group who mentakwilkan perkara based on place, this perkara takwilan for people who understand Arabic and qawa'id and furu' (Al-Nawawi, 1995).

The proof of Imam al-Nawawi's opinion can be found in al-Majmu kitab that is tends to use salaf ijmal not as tafsil:

Meaning: Basic of obligation in Islam and perkara about 'aqidah is enough by tasdiq to everything from Rasul Allah and i'tiqad with it secara jazam and free from any doubtless. And not an obligation for them who reach that faith in studies Mutakallimin argumentations. This is the right one for salaf, fuqaha and Al-Mutakallimin from our friend (al-Asa'irah) and others. It's because prophet did not demand anybody with something except what we said (Al-Nawawi, n.d.).

Based on this fact, imam Al-Nawawi explains that salaf approach is enough for Muslim in aqidah matter but if we find the doubtless from components of hujah of mind, so we can refer to hujah of Mutakallimin as follow:

$$
\text { وأدلة المتكلمين و تشكك والعياد بالله في شيء من اصول العقائد مما لابد من اعتقاده و لم يزل شكه إلا بتعلم دليل من }
$$

Meaning: And if you feel doubt (Islamic asas and 'aqidah) and be under the protection of Allah from usul i'tiqad rather than sebatang perkasa (some basis) yang mesti dipegangi than everything about 'aqidah. And we still feel doubt (Syakk) again, except studied about arguments from all arguments of Mutakallimin's group, become a convincing learning to decline doubtless. That's when we reach usul i'tiqad (Al-Nawawi, n.d.).

It's clear on that imam al-Nawawi book al-Majmu that his opinion is enough with Rasulullah's guideline except with using mutakallimin opinion so they suggested to using it.

Imam al-Nawawi basicly accepts or gives priority to salaf about Allah's character matter ijmaly, but the problem is after he uses ulama Mutakallimin's word in the long way without any comment. It's shows that he agrees with their opinion.

Beside that matter, imam al-Nawawi used to explain salaf stream shortly that is belief in zahir hadits. But if explains about khalaf stream he explains secara panjang lebar that put nas-nas that 
he take from khalaf stream specifically as like al-Maziriy, al-Qadi 'lyad and so on, without any comment.

\section{Method of Explanation of Patani Ulama and Imam Al-Nawawi}

From all Ulama2 Patani's work in explaining akidah about Allah's characters or ayat (verses) founded that there is mix explanation between salaf and khalaf, salaf give all acknowledge will to Allah and khalaf mentakwilkan (interpretation) by followed something deserved to Allah, shortly fact is:

$$
\begin{aligned}
& \text { فرمان الله تعالى:( ويبقى وجه ربك , يد الله فوق أيديهم ) دان تغكل ايت وجه توهنم دان تاغن الله } \\
& \text { دأتس تاغن مريكئيت, مك الخلف واجب كيت تأويلكن يعنى تغكغكن أتس ميالهى ظاهرث مك } \\
& \text { دتأويلكن دأتس كتغكين دان مبساران بوكن دأتس تمفبث ادافون مذهب السلف ايت اداله مريكئيت } \\
& \text { تفويض علموث ايت كفدا الله دان واجب كيت اعتقاد كن سفرة برغيغ ادا فذا ظاهر كتاث دان فدا } \\
& \text { حقيقة كيت جاوهكن سكل ككور اغن }
\end{aligned}
$$

Imam Al-Nawawi explains hadits-hadits about Allah's characters based on mix method between two streams, those are salaf and khalaf, but the stressing is on salaf stream.

That fact shows that similarities between 'akidah ulama in Patani with imam Al-Nawawi on explanation of 'akidah. Just a little bit differensiation that is imam al-Nawawi begin the method of explanation with salaf stream's method then followed by khalaf explanation's method. Patani's ulama begin with khalaf stream's method rather than salaf stream's method.

By using explanation method in Patani's ulama indicates that Patani's ulama open their knowledge about 'akidah explanation to Patanis' society. This is the best way to spreads the knowledge about 'akidah to Patani's society

\section{CONCLUSION}

Based on Patani's ulama works about 'akidah we can categorize their explanation become two streams, those are khalaf stream and salaf stream, but most of them use khalaf stream. However, imam Al-Nawawi when explains 'akidah on Sarh Sahih Muslim book he use mix method explanation between salaf and khalaf, the similarities between imam al-Nawawi and Patani's ulama on 'akidah explanation is they use mix method. 


\section{References}

Abidin, Z. (n.d.). Aqidah al-Najin fi Ilm Usul al-Din. Patani: Matbaah Hallabi.

Abidin2, Z. (n.d.). Miftah al-Murid fi IIm al-Tauhid. Patani: Matbaah Hallabi.

Al-Nawawi, Y. bin S. (n.d.). al-Majmu' Syarh al-Muhadhdhab li al-Syiraziy. Jedah: Maktabah alArsyad.

Al-Nawawi, Y. bin S. (1995). Sahih Muslim bi Syarh Imam Muhy al-Din al-Nawawi. Beirut: Dar alMa'rifah.

Al-Patani, A. bin M. bin M. bin M. (n.d.). al-'Iqd al-Farid fi Ilm al-Tauhid. Patani: Matbaah Dar alMa'arif.

Al-Patani3, A. bin M. bin M. bin M. (n.d.). Urwan al-Falah wa unfuwan al-Salah. Patani: Matbaah Dar al-Ma'arif.

Al-Sakhawiy, M. bin 'Abd al-R. bin A. B. (n.d.). Tarjamah Syeikh al-Islam Abi Zakariya Yahya alNawawi. Misr: Makhtubah al-Azhar al-Syarif.

Idris, D. bin A. bin. (n.d.). al-Dur al-Thamin fi Bayan Aqa'id al-Mu'minin. Patani: Maktabah Muhammad al-Nahdi.

Qadir, I. bin A. (2000). Baqarah al-Amani li Irsyad 'Awam Ahl al-Fatani. Kuala Lumpur: Khazanah al-Pataniah.

Sabuding, A. (2013). Imam al-Nawawi dan Syar Sahih Muslim, Satu kajian ayat-ayat sifat. Universiti Sains Malaysia.

Wangah, A. Q. bin. (n.d.). Mahbath al-Kalam fi Ilm Kalam. Patani: Saudara Peris.

Wangah3, A. Q. bin. (n.d.). Risalah Manhaj Ahl al-Sunnah. In A. bin M. bin M. bin M. Al-Patani (Ed.), "Unwan al-Falah wa" Unfuwan al-Salah. Patani: Saudara Peris. 